\title{
Cloud Seeding Experiment using Common Salt
}

\author{
K. R. Biswas, R. K. Kapoor and K. K. Kanuga \\ National Physical Laboratory of India, New Delhi \\ and Bh. V. Ramana MuRTy \\ Institute of Tropical Meteorology, Poona, India \\ (Manuscript received 30 January 1967, in revised form 2 June 1967)
}

\section{ABSTRACT}

\begin{abstract}
An experiment on artificial stimulation of rain using a warm cloud seeding technique was undertaken in three nearby climatologically similar regions, Delhi, Agra and Jaipur in northwest India. Analysis of the data from 18 experiment-seasons has suggested a positive trend of the result, which is found significant by statistical tests.
\end{abstract}

\section{Introduction}

It is of interest to investigate whether dispersal into cloud air of salt particles of appropriate sizes from the ground would help cause a significant increase in the net yield of rainfall in downwind regions. An experiment was performed with this objective in view at Delhi $\left(28^{\circ} 35^{\prime} \mathrm{N}, 77^{\circ} 12^{\prime} \mathrm{E} ; 714 \mathrm{ft} \mathrm{MSL}\right)$ in 1957 . The results of the preliminary trials of the first three years have been published (Roy et al., 1961).

Despite the principle of randomization followed in the work program, it was considered that it would not be possible to ensure a proper balancing of similar meteorological situations between the two sets of days "seeded" and "not-seeded" unless the trials were repeated over a large number of seasons. The experiment, therefore, had to involve a continuing program at Delhi. Also, with a view to arriving at a definite conclusion in a shorter period, the program was later extended to two nearby climatologically similar regions, Agra $\left(27^{\circ} 10^{\prime} \mathrm{N}, 78^{\circ} 10^{\prime} \mathrm{E} ; 353 \mathrm{ft} \mathrm{MSL}\right)$ and Jaipur $\left(26^{\circ} 35^{\prime} \mathrm{N}, 7^{\circ} 50^{\prime} \mathrm{E} ; 1431 \mathrm{ft} \mathrm{MSL}\right)$. A map showing locations of the three experiments is given in Fig. 1. The experiment at Agra continued for six consecutive monsoon seasons, and that at Jaipur for four seasons. The available data relating to the trials conducted at the three stations are presented and discussed in the following.

\section{Design of the experiment}

a. Choice of control and target sectors. Fixation of control and target sectors was based on the assumption that a substantial portion of the particles released from ground-based generators would drift in the direction of the mean wind and eventually reach cloud heights. The considerations which provided a basis in support of this assumption have been discussed in Roy et al. (1961). It was further found that the wind at the $1.5-\mathrm{km}$ level, the mean height of the base of convective clouds in the region during monsoon seasons, provided a good index of the mean wind from the surface up to $2.5 \mathrm{~km}$. An analysis was accordingly made of the daily wind data for this height during monsoon season for 5 years, 1950-1954 for Delhi, 1936-1940 for Agra, and 1954-1958 for Jaipur. The angular spread of the target area has been assumed to cover the entire $90^{\circ}$ quadrant opposite to that in which the mean wind direction lay as indicated by the analysis. The control and target sectors fixed in this manner for Delhi, Agra and Jaipur are as shown in Table 1. There are thus two sets each of control and target sectors for Delhi and Agra and three sets for Jaipur.

b. Raingage networks, areas of operation, and certain broad climatological fealures of the regions. A close network of raingages having a gage density of about 1 per $20 \mathrm{mi}^{2}$ (Fig. 2) was installed within $15 \mathrm{mi}$ of Delhi. (A few of the raingages shown in the figure were functioning prior to the program.) The extent of $15 \mathrm{mi}$ considered for the target sector was based on the reasoning that with convective cloud cells lying in the path of the diffusing material and with vertical currents within them being much stronger and horizontal winds weaker, the particles released would reach cloud height at a much closer range than otherwise. However, the sectors have been extended up to $25 \mathrm{mi}$ from the seeding site in the case of the experiment at Agra and Jaipur, for it was felt subsequently that the 15-mi extent considered in the case of Delhi was on the low side. The raingage networks installed around Agra (Fig. 3) and Jaipur (Fig. 4) were based on this revised consideration. As the total number of raingages installed around each of these places was about half of that installed at 


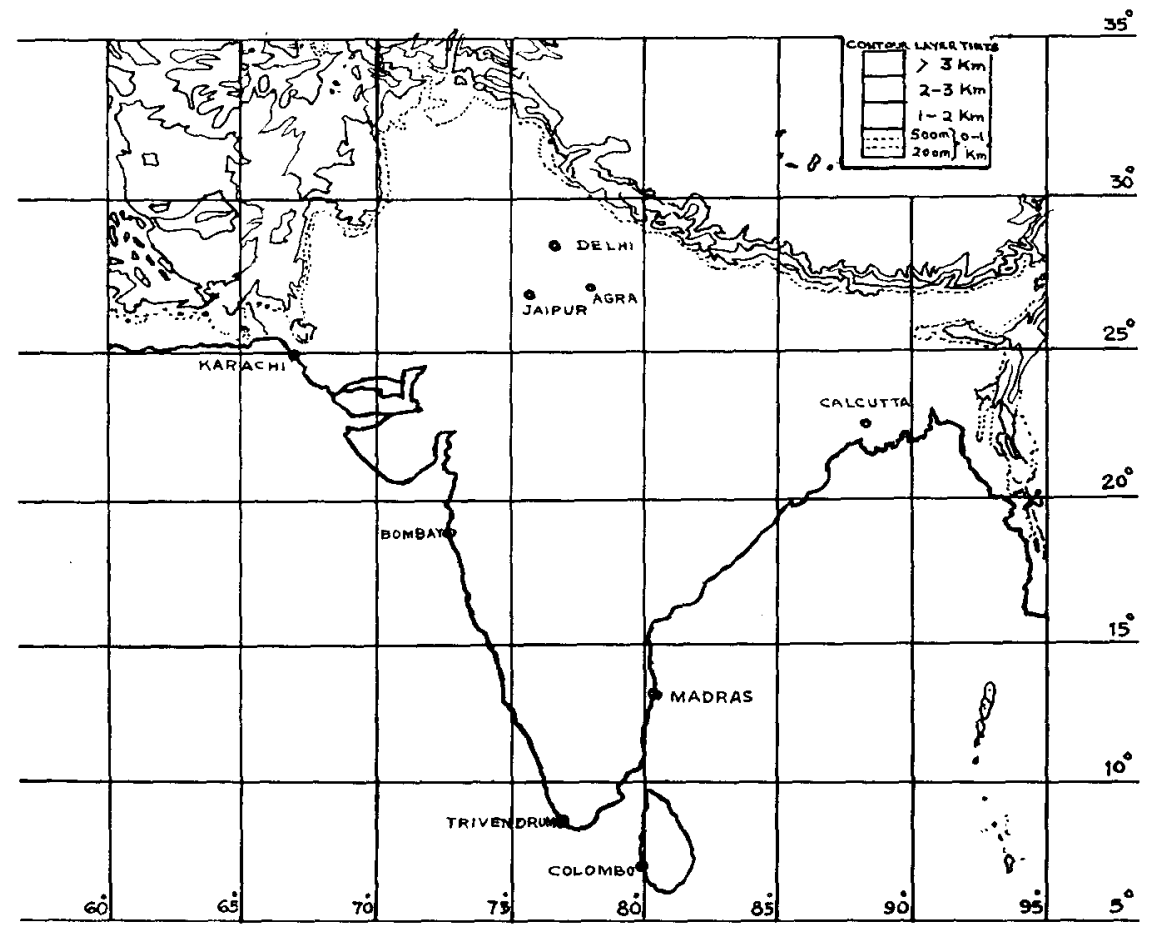

FIG. 1. Indian sub-continent: location of Delhi, Agra and Jaipur.

Delhi within a closer range, the density of the networks at Agra and Jaipur was only about 1 per $115 \mathrm{mi}^{2}$ The actual selection of raingage locations at each of the places has been based on a number of considerations such as availability of easy access to sites, availability of local observers for maintenance and collection of data, and presence of any natural obstacles such as river beds, etc., in the vicinity (as in the case of Agra and Jaipur). The area of the target and control sectors is about $175 \mathrm{mi}^{2}$ in the case of Delhi and $490 \mathrm{mi}^{2}$ in the case of Agra and Jaipur. It is to be noted in this connection that on account of these dissimilarities with respect to region in the extent of target/control sectors, and in the density of the raingage networks, some bias could have entered into the design of the experiment.

The predominant clouds in the regions of the three experimental sites during the season are of a convective type, permitting a fair degree of insolational heating of the ground and consequent rising currents in the lower air layers on many of the afternoons, a factor which favors attempted nucleation of clouds by particles released from the ground. The monsoon trough line which demarcates the prevailing southeasterly Bay monsoon air flowing up the Gangetic valley from the southwesterly Arabian sea monsoon over western and central India runs, on the mean, fairly close to Delhi and Agra and a little to the north of Jaipur. With the shift of this line north or south of the stations, the respective area under experiment comes alternately under the influence of air currents with easterly or westerly components. The cloud, rainfall and general weather features differ noticeably in the three broad situations. In situations when the trough line passes close to the station and the monsoon trough is well marked, the weather is often unsettled and rain, more

TABLE 1, Control and target sectors for Delhi, Agra and Jaipur.

\begin{tabular}{|c|c|c|c|c|c|c|}
\hline \multirow[b]{2}{*}{ Month } & \multicolumn{2}{|c|}{ Delhi } & \multicolumn{2}{|c|}{ Agra } & \multicolumn{2}{|c|}{ Jaipur } \\
\hline & $\begin{array}{l}\text { Controi } \\
\text { sector }\end{array}$ & $\begin{array}{l}\text { Target } \\
\text { sector }\end{array}$ & $\begin{array}{l}\text { Control } \\
\text { sector }\end{array}$ & $\begin{array}{l}\text { Target } \\
\text { sector }\end{array}$ & $\begin{array}{l}\text { Control } \\
\text { sector }\end{array}$ & $\begin{array}{l}\text { Target } \\
\text { sector }\end{array}$ \\
\hline July & $\begin{array}{r}90^{\circ}-180^{\circ} \\
270^{\circ}-360^{\circ}\end{array}$ & $\begin{array}{r}270^{\circ}-360^{\circ} \\
90^{\circ}-180^{\circ}\end{array}$ & $\begin{array}{r}45^{\circ}-135^{\circ} \\
270^{\circ}-360^{\circ}\end{array}$ & $\begin{array}{r}225^{\circ}-315^{\circ} \\
90^{\circ}-180^{\circ}\end{array}$ & $\begin{array}{l}180^{\circ}-270^{\circ} \\
270^{\circ}-360^{\circ}\end{array}$ & $\begin{array}{r}0^{\circ}-90^{\circ} \\
90^{\circ}-180^{\circ}\end{array}$ \\
\hline August & $\begin{array}{r}90^{\circ}-180^{\circ} \\
270^{\circ}-360^{\circ}\end{array}$ & $\begin{array}{r}270^{\circ}-360^{\circ} \\
90^{\circ}-180^{\circ}\end{array}$ & $\begin{array}{r}45^{\circ}-135^{\circ} \\
270^{\circ}-360^{\circ}\end{array}$ & $\begin{array}{r}225^{\circ}-315^{\circ} \\
90^{\circ}-180^{\circ}\end{array}$ & $\begin{array}{l}180^{\circ}-270^{\circ} \\
270^{\circ}-360^{\circ}\end{array}$ & $\begin{array}{r}0^{\circ}-90^{\circ} \\
90^{\circ}-180^{\circ}\end{array}$ \\
\hline September & $\begin{array}{r}90^{\circ}-180^{\circ} \\
270^{\circ}-360^{\circ}\end{array}$ & $\begin{array}{r}270^{\circ}-360^{\circ} \\
90^{\circ}-180^{\circ}\end{array}$ & $\begin{array}{r}45^{\circ}-135^{\circ} \\
270^{\circ}-360^{\circ}\end{array}$ & $\begin{array}{r}225^{\circ}-315^{\circ} \\
90^{\circ}-180^{\circ}\end{array}$ & $\begin{array}{r}0^{\circ}-90^{\circ} \\
270^{\circ}-360^{\circ}\end{array}$ & $\begin{array}{r}180^{\circ}-270^{\circ} \\
90^{\circ}-180^{\circ}\end{array}$ \\
\hline
\end{tabular}




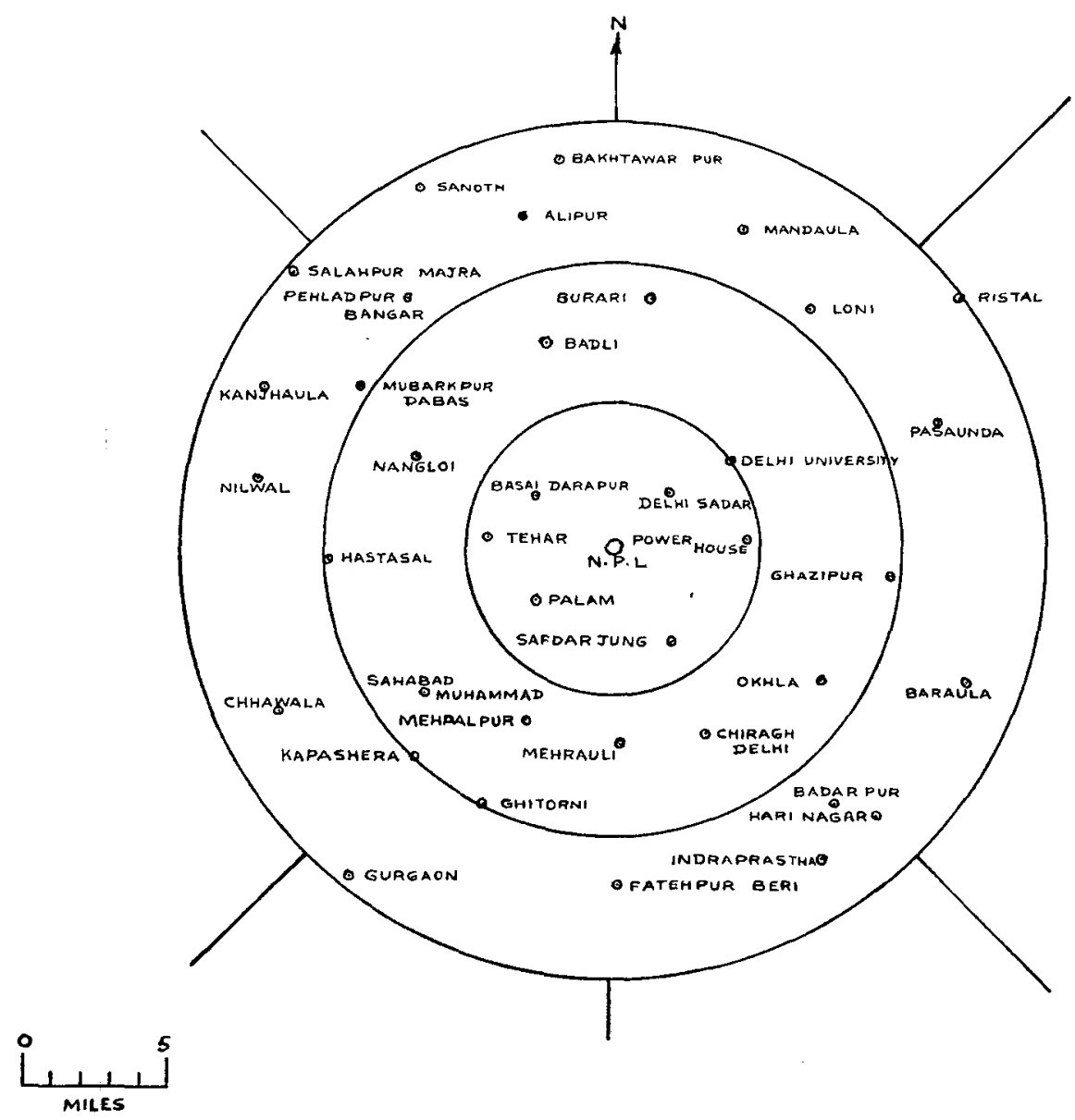

FIG. 2. Location of raingages around Delhi.

or less continuous, occurs from deep stratiform type clouds. In the other two situations, rain is mostly of an intermittent or showery nature, and the predominant rain-giving clouds are cumulus congestus or cumulonimbus, the average cloud cover being somewhat more on days when the winds have an easterly component than on days when the winds have a westerly component. The weather is mainly dry and often cloudless when the trough lies too far to the north or south of the station. Instances in which the trough lies very far to the south of Jaipur are rather rare.

The annual total rainfall at each of the experiment stations Delhi, Agra and Jaipur is nearly the same at about 25 inches. Rain occurs on the average at these places about 36 days a year. About $75 \%$ of the year's total rain is received during the three monsoon months July to September. The number of non-rainy days with cloud amount $\frac{3}{8}$ or more is nearly the same for the three regions during the monsoon season as shown in Table 2.

c. Selection of days for seeding. The program of seeding was conducted on the basis of randomization, a scheme which, within itself, embodies seeded and control areas as well as seeded and not-seeded days, and thereby provides essential control data for evaluation of the trials. The choice of a seedable day was based on the advice obtained daily from the local weather forecasting office regarding 1 ) wind direction at the 1 - and $1.5-\mathrm{km}$ levels, and 2) the actual or expected cloud conditions and probability of rain occurrence over and around the three regions during the next $12 \mathrm{hr}$. The advice was obtained daily at about 1030 IST and the decision regarding whether the day was seedable or not was made immediately after that. A series of random. numbers (Fisher and Yates, 1953), different for the three different regions, predetermined, before the commencement of the monsoon, whether seeding should be carried out on a particular seedable day or not in the monsoon. The choice whether seeding should be done on the "odd" or "even" numbered day was made once and for all for each region by lots. Days on which rain occurred frequently or continuously during the mid-day period were treated as unseedable. Also, those days on which seeding, after having continued for a short period, was later suspended on account of rain have been treated as unseedable and the data from these days have not been considered. However, as there was 


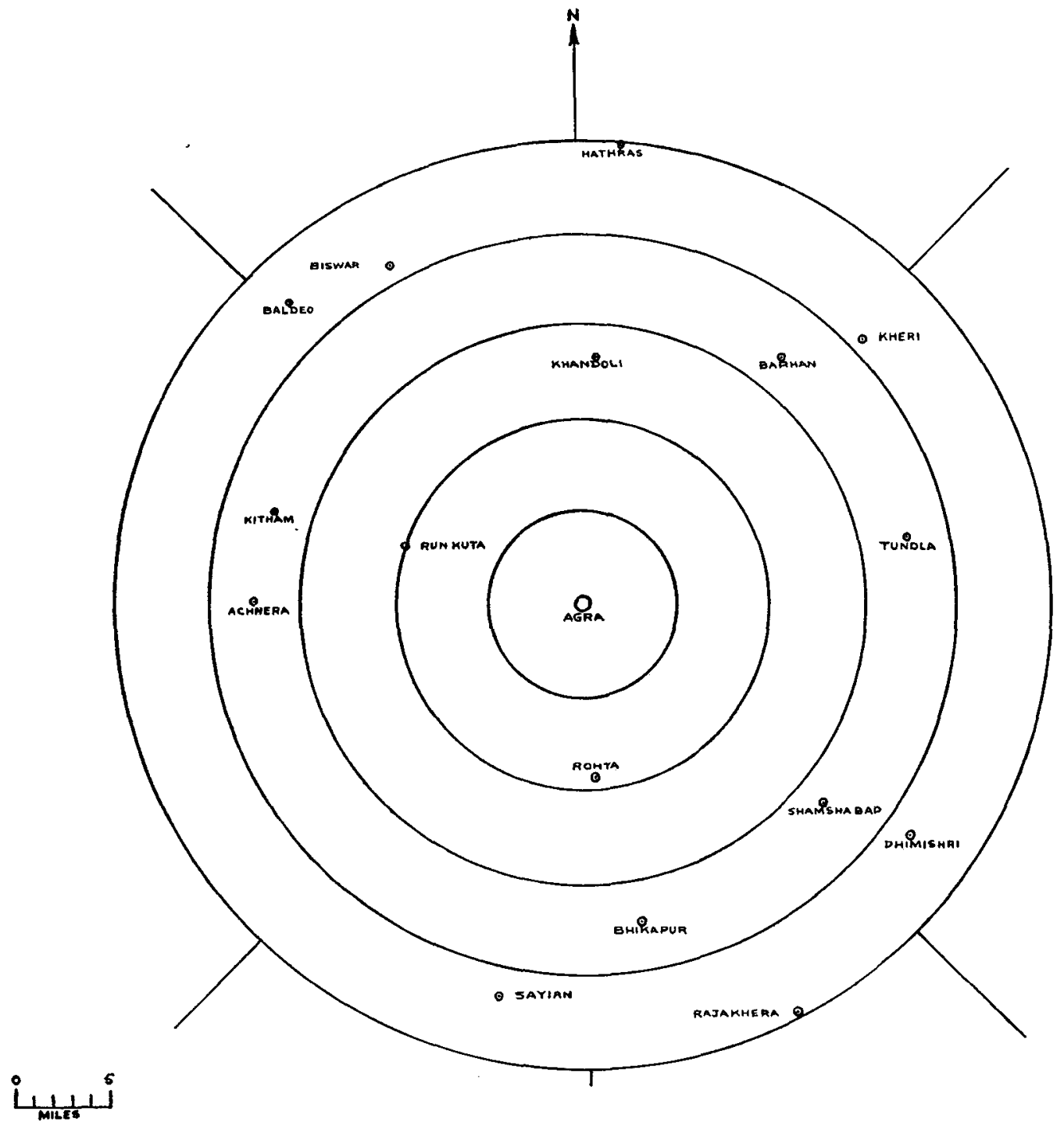

Fig. 3. Location of raingages around Agra.

no rigid criterion set for the optimum time period over which the seeding should have continued on such days to justify their inclusion among "seedable" days, bias could have entered into the design of the experiment in the process of classifying such days as "seedable." Also, those "seedable" days on which there were equipment failures have been considered as unseedable. The three monsoon months, July to September, constituted the seeding period in each year.

d. Data for analysis. Rainfall amounts measured in the target and control sectors by a network of 10-12 raingages in the case of Delhi and 3-5 raingages each

TABLE 2. Rainfall statistics for Delhi, Agra and Jaipur.*

\begin{tabular}{|c|c|c|c|c|c|c|c|}
\hline Station & Latitude & Longitude & $\begin{array}{l}\text { Annual total } \\
\text { rainfall } \\
\text { (inches) }\end{array}$ & $\begin{array}{l}\text { Rainfall } \\
\text { during } \\
\text { monsoon } \\
\text { (inches) }\end{array}$ & $\begin{array}{l}\text { Total num- } \\
\text { ber of } \\
\text { rainy days }\end{array}$ & $\begin{array}{l}\text { Number of } \\
\text { rainy days } \\
\text { during } \\
\text { monsoon }\end{array}$ & $\begin{array}{l}\text { Number of days } \\
\text { during mon- } \\
\text { soon with } \frac{3}{8} \\
\text { cloud cover } \\
\text { or more }\end{array}$ \\
\hline $\begin{array}{l}\text { Delhi } \\
\text { Agra } \\
\text { Jaipur }\end{array}$ & $\begin{array}{l}28^{\circ} 35^{\prime} \\
27^{\circ} 10^{\prime} \\
26^{\circ} 55^{\prime}\end{array}$ & $\begin{array}{l}77^{\circ} 12^{\prime} \\
78^{\circ} 02^{\prime} \\
75^{\circ} 50^{\prime}\end{array}$ & $\begin{array}{l}26.24 \\
26.74 \\
24.02\end{array}$ & $\begin{array}{l}19.10 \\
21.24 \\
19.02\end{array}$ & $\begin{array}{l}36.1 \\
37.4 \\
35.6\end{array}$ & $\begin{array}{l}22.6 \\
26.9 \\
25.2\end{array}$ & $\begin{array}{l}62 \\
66 \\
61\end{array}$ \\
\hline
\end{tabular}

* Based on Climatological Tables of Observatories in India, 1953, India Meteorological Department. 


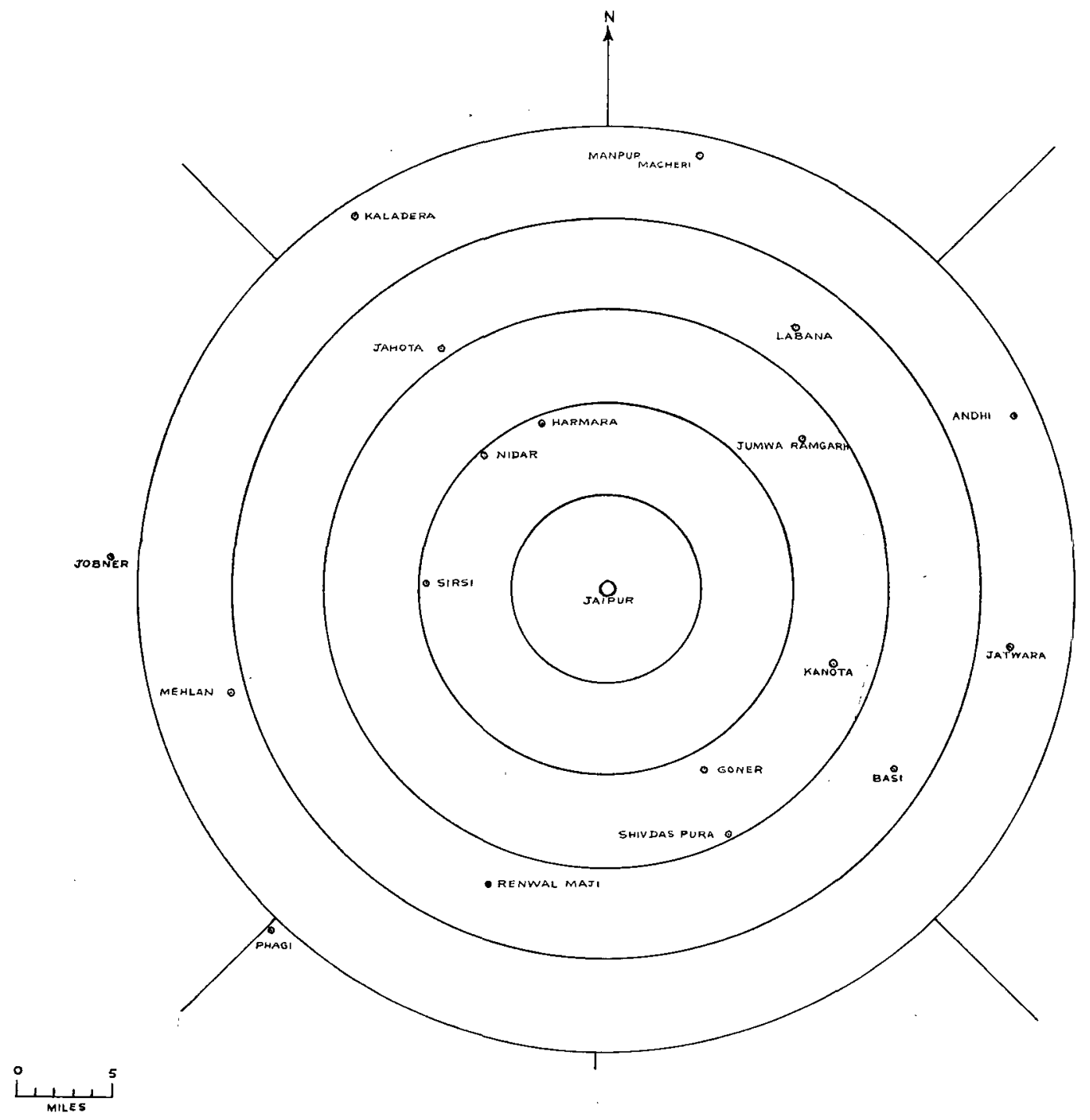

FIG. 4. Location of raingages around Jaipur.

in the case of Agra and of Jaipur provided the basic data for analysis. The raingages used are of the 5-inch standard India Meteorological Department type, and are read once daily at 0830 IST. The raingage readers who are mostly local school teachers were completely unaware as to which days were seeded.

\section{Details of the seeding operation}

Hygroscopic particles were fed into the lower air layers either by ground spraying of a dilute salt solution of known concentration by using power sprayers and air compressors, or by dusting a finely powdered salt mixture with the help of air compressors. In the case of liquid spraying, the solution used had a concentration of one pound of common salt in a gallon of water, giving an equilibrium relative humidity over the solution of $95 \%$. The rate of spraying was about a gallon of solution in 5-6 min at a pressure of $125 \mathrm{psi}$. As stated earlier (Roy et al., 1961), the rate of dispersal, by such operations, of particles having dry masses ranging from $4 \times 10^{-10}$ to $10^{-8} \mathrm{gm}$, or diameters of 7-25 $\mu$, was of the order of $10^{9} \mathrm{sec}^{-1}$ at the source. In the case of dry dusting, the salt mixture used contained common salt and soapstone in the proportion 9:1 (soapstone permitting dusting of the material as separate tiny particles), and the mixture ground to a fine powder so that the median particle mass is approximately $10^{-9} \mathrm{gm}$, corresponding to a dry particle radius of about $5 \mu$. The rate of dispersal was about $2500 \mathrm{gm}$ of the salt mixture per minute. Assuming that $50 \%$ of the particles released are lost by falling back to the ground, this rate of dispersal at the source yields about $2 \times 10^{10}$ giant size hygroscopic particles per second. A rough estimate made of the order of concentration at a dis- 
tance of $15 \mathrm{mi}$ on the basis of 1) the dispersal rate at the source, 2) the mean wind speed, and 3) a relationship of the inverse 1.76th power of distance (Sutton, 1953 ), yields values, roughly about 200 and $2000 \mathrm{~m}^{-3}$, for the liquid and dry particle releasing systems, respectively. The above estimate, involving extrapolation over a considerable distance of a relationship which is founded on experimental determination of conditions within a limited range only, may not be quite dependable, particularly when the target area has been considered as spread over as wide an angle as $90^{\circ}$.

Seeding operations were carried out on each seeded day for a period of 3-5 hr beginning about $1 \mathrm{hr}$ before noon when there would be a fair degree of insolational heating of ground and consequent up-currents in the lower air layers to carry the particles aloft. The number of seeded and not-seeded days during the $18 \mathrm{ex}$ periment-seasons considered totalled 435 and 432 , respectively. Table 3 gives the breakdown by year for each region with reference to the wind direction. The year 1962 for Delhi has been omitted from the table because seeding during that year was carried out from aircraft according to random pairs (Roy et al., 1964).

\section{Evaluation of seeding trials}

Comparisons were made of the ratio $T / C$ of rain over the target to that over the control sector, relative to the two groups of seedable days-one seeded and the other not-seeded. A higher ratio value for seeded days compared to that for the not-seeded is taken as suggestive of a positive trend of the result. Tables $4 a-4 c$ give values of the ratio $T / C$ for mean amounts of precipitation per raingage station in the test areas at Delhi, Agra and Jaipur during each monsoon season on seeded and not-seeded days. The data indicate a positive trend of the result in trials made during 7 out of the 8 seasons at Delhi, 5 out of the 6 at Agra, and all 4 at Jaipur. The results when considered with respect to the wind (Tables $4 \mathrm{~d}-4 \mathrm{f}$ ) showed a positive trend in 14 out of the 16 trial units at Delhi, 8 out of the 12 at Agra and 5 out of the 12 at Jaipur.

\section{Rainfall totals and double ratios for Delhi}

The opposite quadrant target and control sectors in this region were interchangeable on seeded days depending upon the direction of the mean wind. As the days selected for seeding from among the seedable days was based only on the numbers in the random series, it is tantamount to conducting the experiment at Delhi in two adjacent areas, the area to be seeded being determined by the wind direction. Designating the sectors as east and west, the mean rainfall amounts per station in the eastern and western sectors on the east-seeded (Ee and $\mathrm{We}$ ) and west-seeded (Ew and Ww) occasions for each monsoon season and for all the seasons combined are given in Table 5. The double ratio
TABLE 3. Number of seeded and not-seeded days.

a. Delhi

\begin{tabular}{|c|c|c|c|c|}
\hline \multirow[b]{2}{*}{ Year } & \multicolumn{2}{|c|}{$\begin{array}{l}\text { Winds from SE } \\
\text { quadrant }\end{array}$} & \multicolumn{2}{|c|}{$\begin{array}{c}\text { Winds from NW } \\
\text { quadrant }\end{array}$} \\
\hline & Seeded & $\begin{array}{l}\text { Not- } \\
\text { seeded }\end{array}$ & Seeded & $\begin{array}{l}\text { Not- } \\
\text { seeded }\end{array}$ \\
\hline 1957 & 10 & 13 & 9 & 3 \\
\hline 1958 & 21 & 17 & 11 & 7 \\
\hline 1959 & 21 & 18 & 11 & 11 \\
\hline 1960 & 10 & 8 & 4 & 11 \\
\hline 1961 & 21 & 13 & 11 & 13 \\
\hline 1963 & 16 & 10 & 9 & 7 \\
\hline 1964 & 12 & 14 & 12 & 13 \\
\hline \multirow[t]{2}{*}{1965} & 11 & 10 & 10 & 11 \\
\hline & 122 & 103 & 77 & 76 \\
\hline \multicolumn{5}{|c|}{ b. Agra } \\
\hline
\end{tabular}

\begin{tabular}{|c|c|c|c|c|c|c|}
\hline \multirow[b]{2}{*}{ Year } & \multicolumn{4}{|c|}{ Winds from $45^{\circ}-135^{\circ}$} & \multicolumn{2}{|c|}{$\begin{array}{c}\text { Winds from NW } \\
\text { quadrant }\end{array}$} \\
\hline & & Seeded & \multicolumn{2}{|c|}{$\begin{array}{l}\text { Not- } \\
\text { seeded }\end{array}$} & Seeded & $\begin{array}{l}\text { Not- } \\
\text { seeded }\end{array}$ \\
\hline 1960 & & 7 & \multicolumn{2}{|l|}{7} & 10 & 8 \\
\hline 1961 & & 16 & \multicolumn{2}{|l|}{12} & 9 & 9 \\
\hline 1962 & & 18 & \multicolumn{2}{|l|}{13} & 13 & 18 \\
\hline 1963 & & 6 & \multicolumn{2}{|l|}{15} & 17 & 14 \\
\hline 1964 & & 10 & \multicolumn{2}{|l|}{12} & 12 & 12 \\
\hline \multirow[t]{2}{*}{1965} & & 16 & \multicolumn{2}{|l|}{8} & 6 & 8 \\
\hline & & 73 & \multicolumn{2}{|l|}{67} & 67 & 69 \\
\hline \multicolumn{7}{|c|}{ c. Jaipur } \\
\hline & \multicolumn{2}{|c|}{$\begin{array}{l}\text { Winds from } \\
\text { NE quadrant }\end{array}$} & \multicolumn{2}{|c|}{$\begin{array}{l}\text { Winds from } \\
\text { SW quadrant }\end{array}$} & \multicolumn{2}{|c|}{$\begin{array}{l}\text { Winds from } \\
\text { NW quadrant }\end{array}$} \\
\hline Year & Seeded & $\begin{array}{c}\text { Not- } \\
\text { seeded }\end{array}$ & Seeded & $\begin{array}{c}\text { Not- } \\
\text { seeded }\end{array}$ & Seeded & $\begin{array}{l}\text { Not- } \\
\text { seeded }\end{array}$ \\
\hline 1960 & 2 & 3 & 8 & 10 & 15 & 14 \\
\hline 1961 & 5 & 11 & 9 & 4 & 12 & 14 \\
\hline 1962 & 2 & 7 & 4 & 5 & 19 & 19 \\
\hline \multirow[t]{2}{*}{1963} & 2 & 3 & 3 & 6 & 16 & 21 \\
\hline & 11 & 24 & 24 & 25 & 62 & 68 \\
\hline
\end{tabular}

$(\mathrm{Ee} / \mathrm{We}) /(\mathrm{Ew} / \mathrm{We})$, i.e., the ratio of precipitation in the east area to that in the west area during east seeded periods divided by similar ratio during west seeded periods is given in the table. Considering that the expected value of this double ratio is unity if seeding has no effect and that a positive seeding effect would increase both the numerator factors without affecting the denominator, it is seen from the table that trials made during 7 out of the 8 seasons at Delhi indicated a positive trend of result. A similar type of evaluation could not be extended to the trials made at Agra and Jaipur because the target and control sectors are not strictly interchangeable, as in the case of Delhi.

\section{Probable augmentation of rainfall as a result of seeding}

The amount of rainfall recorded in the target and control areas on seeded and not-seeded days during the 8-yr seeded period at Delhi (1957-1965, excluding 1962), the 6-yr seeded period at Agra (1960-65) and the 4-yr seeded period at Jaipur (1960-63) are given in Table 6. 
TABLE 4. Rainfall (mm) per station in target $(T$ and control $(C)$ sectors.

a. Delhi

\begin{tabular}{|c|c|c|c|c|c|c|c|}
\hline \multirow[t]{2}{*}{ Year } & \multicolumn{3}{|c|}{ Seeded } & \multicolumn{3}{|c|}{ Not-seeded } & \multirow[t]{2}{*}{ Result } \\
\hline & $T$ & C & $T / C$ & $T$ & $C$ & $T / C$ & \\
\hline 1957 & 128.7 & 122.6 & 1.05 & 85.8 & 144.6 & 0.59 & Positive \\
\hline 1958 & 143.7 & 185.7 & 0.77 & 124.0 & 206.0 & 0.60 & Positive \\
\hline 1959 & 160.3 & 135.2 & 1.19 & 172.9 & 138.9 & 1.24 & Negative \\
\hline 1960 & 60.2 & 52.3 & 1.15 & 158.6 & 146.9 & 1.08 & Positive \\
\hline 1961 & 165.6 & 103.0 & 1.61 & 152.1 & 180.3 & 0.84 & Positive \\
\hline 1963 & 273.0 & 143.6 & 1.90 & 62.7 & 99.4 & 0.63 & Positive \\
\hline 1964 & 305.8 & 170.4 & 1.80 & 403.7 & 279.1 & 1.45 & Positive \\
\hline \multirow[t]{2}{*}{1965} & 50.6 & 43.8 & 1.16 & 57.2 & 86.2 & 0.66 & Positive \\
\hline & \multicolumn{6}{|c|}{ b. Agra } & \\
\hline \multirow[t]{2}{*}{ Year } & \multicolumn{3}{|c|}{ Seeded } & \multicolumn{3}{|c|}{ Not-seeded } & Result \\
\hline & $T$ & $C$ & $T / C$ & $T$ & C & $T / C$ & \\
\hline 1960 & 223.7 & 155.1 & 1.44 & 98.2 & 111.2 & 0.88 & Positive \\
\hline 1961 & 209.0 & 160.6 & 1.30 & 105.3 & 90.2 & 1.17 & Positive \\
\hline 1962 & 106.9 & 135.0 & 0.79 & 185.9 & 181.3 & 1.03 & Negative \\
\hline 1963 & 111.9 & 76.3 & 1.47 & 210.3 & 277.9 & 0.76 & Positive \\
\hline 1964 & 145.8 & 70.9 & 2.06 & 127.6 & 170.4 & 0.75 & Positive \\
\hline 1965 & 196.7 & 94.3 & 2.09 & 145.0 & 143.8 & 1.01 & Positive \\
\hline
\end{tabular}

c. Jaipur

\begin{tabular}{|c|c|c|c|c|c|c|c|}
\hline \multirow[t]{2}{*}{ Year } & \multicolumn{3}{|c|}{ Seeded } & \multicolumn{3}{|c|}{ Not-seeded } & \multirow[t]{2}{*}{ Result } \\
\hline & $T$ & $C$ & $T / C$ & $T$ & $C$ & $T / C$ & \\
\hline 1960 & 131.8 & 74.7 & 1.76 & 134.1 & 79.2 & 1.69 & Positive \\
\hline 1961 & 138.7 & 118.4 & 1.17 & 186.0 & 179.1 & 1.04 & Positive \\
\hline 1962 & 90.0 & 85.9 & 1.05 & 180.9 & 182.5 & 0.99 & Positive \\
\hline 1963 & $7 \pi, 0$ & 50.7 & 1.52 & 122.3 & 116.3 & 1.05 & Positive \\
\hline
\end{tabular}

The data suggest an effective increase in rainfall of $41.6 \%, 58.5 \%$ and $18.6 \%$ in the experimental areas at Delhi, Agra and Jaipur, respectively. Combining the values for the three stations, the net increase in rainfall effected as a result of the experiment is $41.9 \%$.

Analysis of rainfall totals by the double ratio method (the square root of the double ratio for the entire 8-yr period being 1.37, as shown in the last column of Table 5) suggested that precipitation on seeded days exceeded that on not-seeded days by $37 \%$ at Delhi.

\section{Statistical analysis}

Three methods of analysis of the ratio $T / C$, as given in Tables $4 a-4 c$, of the precipitation in the target and control areas on seeded and not-seeded days were undertaken. These were 1 ) the median ratio test (Kendall, 1943), 2) the Wilcoxon test (Mann and Whitney, 1947), and 3) the $t$-test (Moran, 1959). The results of this evaluation are given in Table $7 \mathrm{a}$ by region and for all the three regions combined.

Delhi and Agra indicated acceptable levels of significance where as Jaipur showed low significance. The combined significance levels were high (median ratio, 0.0025 ; Wilcoxon, 0.0017 ; and $t$-test 0.005 ).

The tests were also applied in the case of Delhi to the values obtained for the ratio of precipitation in the

Rainfall $(\mathrm{mm})$ per station in target $(T)$ and control $(C)$ sectors with respect to wind direction.

d. Delhi

\begin{tabular}{|c|c|c|c|c|c|c|c|c|c|c|c|c|c|c|}
\hline \multirow{3}{*}{ Year } & \multicolumn{6}{|c|}{ Winds from SE quadrant } & \multicolumn{8}{|c|}{ Winds from NW quadrant } \\
\hline & \multicolumn{3}{|c|}{ Seeded } & \multicolumn{3}{|c|}{ Not-seeded } & \multirow[b]{2}{*}{ Result } & \multicolumn{3}{|c|}{ Seeded } & \multicolumn{3}{|c|}{ Not-seeded } & \multirow[t]{2}{*}{ Result } \\
\hline & $T$ & $C$ & $T / C$ & $T$ & $C$ & $T / C$ & & $T$ & $C$ & $T / C$ & $T$ & $C$ & $T / C$ & \\
\hline 1957 & 104.6 & 113.3 & 0.92 & 76.7 & 110.3 & 0.70 & Positive & 24.1 & 9.3 & 2.59 & 9.1 & 34.3 & 0.27 & Positive \\
\hline 1958 & 84.8 & 126.8 & 0.67 & 89.9 & 171.0 & 0.53 & Positive & 58.9 & 58.9 & 1.00 & 34.0 & 35.0 & 0.97 & Positive \\
\hline 1959 & 89.4 & 72.8 & 1.23 & 85.1 & 52.6 & 1.62 & Negative & 70.9 & 62.4 & 1.14 & 87.8 & 86.3 & 1.02 & Positive \\
\hline 1960 & 51.9 & 45.3 & 1.15 & 77.0 & 39.0 & 1.97 & Negative & 8.3 & 7.0 & 1.19 & 81.6 & 106.9 & 0.76 & Positive \\
\hline 1961 & 50.0 & 27.1 & 1.85 & 27.2 & 35.7 & 0.76 & Positive & 115.6 & 75.9 & 1.52 & 124.9 & 144.5 & 0.86 & Positive \\
\hline 1963 & 214.6 & 123.2 & 1.74 & 43.8 & 85.9 & 0.51 & Positive & 58.4 & 20.4 & 2.86 & 18.9 & 13.5 & 1.40 & Positive \\
\hline 1964 & 97.8 & 45.4 & 2.15 & 138.3 & 104.2 & 1.33 & Positive & 207.9 & 125.0 & 1.66 & 265.5 & 174.9 & 1.52 & Positive \\
\hline 1965 & 27.4 & 28.9 & 0.95 & 45.7 & 75.5 & 0.61 & Positive & 23.1 & 14.9 & 1.55 & 11.4 & 10.8 & 1.06 & Positive \\
\hline
\end{tabular}

e. Agra

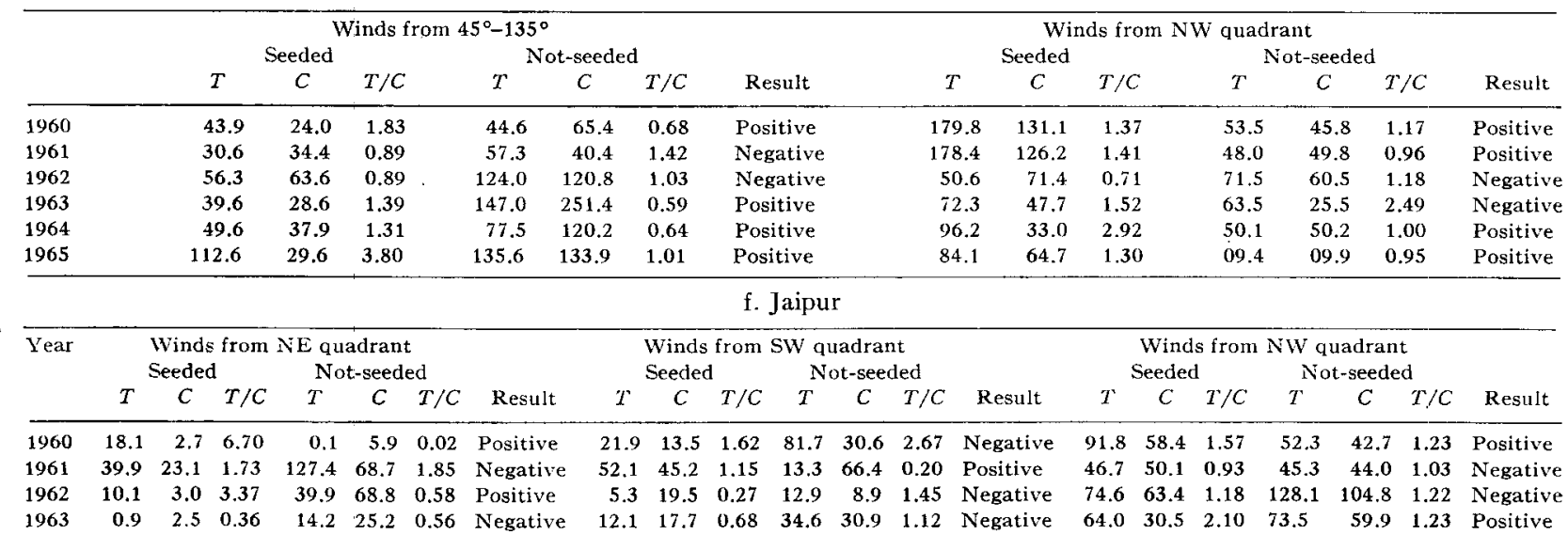


Table 5. Mean precipitation (mm) per station on seeded days for Delhi.

\begin{tabular}{|c|c|c|c|c|c|c|c|c|c|c|}
\hline $\begin{array}{l}\text { Wind } \\
\text { direction }\end{array}$ & Sector & 1957 & 1958 & 1959 & $\begin{array}{l}\text { Year } \\
1960\end{array}$ & 1961 & 1963 & 1964 & 1965 & $1957-65$ \\
\hline$N W$ (east seeded) & $\begin{array}{l}\text { Eastern (Ee) } \\
\text { Western (We) }\end{array}$ & $\begin{array}{r}24.1 \\
9.3\end{array}$ & $\begin{array}{l}58.9 \\
58.9\end{array}$ & $\begin{array}{l}70.9 \\
62.4\end{array}$ & $\begin{array}{l}8.3 \\
7.0\end{array}$ & $\begin{array}{r}115.6 \\
75.9\end{array}$ & $\begin{array}{l}58.4 \\
20.4\end{array}$ & $\begin{array}{l}208.0 \\
125.1\end{array}$ & $\begin{array}{l}23.1 \\
14.9\end{array}$ & $\begin{array}{l}567.3 \\
373.9\end{array}$ \\
\hline \multirow[t]{3}{*}{ SE (west seeded) } & $\begin{array}{l}\text { Eastern (Ew) } \\
\text { Western }\left(W^{r}\right)\end{array}$ & $\begin{array}{l}113.3 \\
104.6\end{array}$ & $\begin{array}{r}126.8 \\
84.8\end{array}$ & $\begin{array}{l}72.8 \\
89.4\end{array}$ & $\begin{array}{l}45.3 \\
51.9\end{array}$ & $\begin{array}{l}27.1 \\
50.0\end{array}$ & $\begin{array}{l}123.2 \\
214.6\end{array}$ & $\begin{array}{l}45.3 \\
97.8\end{array}$ & $\begin{array}{l}28.9 \\
27.4\end{array}$ & $\begin{array}{l}582.7 \\
720.5\end{array}$ \\
\hline & $\frac{\mathrm{Ee} / \mathrm{We}}{\mathrm{Ew} / \mathrm{Ww}}$ & 2.392 & 0.669 & 1.395 & 1.359 & 2.810 & 4.988 & 3.592 & 1.469 & 1.876 \\
\hline & $\sqrt{\frac{\mathrm{Ee} / \mathrm{We}}{\mathrm{Ew} / \mathrm{Ww}}}$ & 1.546 & 0.818 & 1.181 & 1.166 & 1.676 & 2.233 & 1.895 & 1.213 & 1.370 \\
\hline
\end{tabular}

eastern sector to that in the western sector divided into east-seeded and west-seeded ratios. The results, given in Table $7 \mathrm{~b}$ indicate high levels of significance.

The experiment was conducted in one region for 8 seasons, in another for 6 seasons and in yet another for 4 seasons. We may thus consider, for all intents and purposes, that the experiment was conducted for 18 seasons in a single region. On this basis we see that the results obtained in 16 out of 18 seasons are positive with 2 being negative. The findings suggest that the difference in precipitation between the seeded and not-seeded periods in the present experiment is unlikely to have been due to chance.

\section{Effects of seeding with respect to cloud type and rainfall amount}

The comparative effects of seeding 1) with respect to the type of rainbearing cloud (cumuliform and stratiform), and with respect to the amount of control area precipitation (Siliceo et al., 1963) may well be different. These features are examined below.

a. Type of predominant cloud. All the seedable days at Delhi beginning from the monsoon season of 1960 have been classified according to the significant type of precipitating cloud, cumuliform or stratiform, on the basis of the nature of the rain cells shown by a $3.2-\mathrm{cm}$ radar in operation at the experimental site. The ratio of precipitation in the target and control sectors on the seeded and not-seeded days is shown in Table 8 , by season for the two types of cloud situations. The data indicate a positive trend of result in all the 5 seasons

TaBle 6. Total rainfall $(\mathrm{mm})$ per station in target $(T)$ and control $(C)$ sectors during all the seeded and not-seeded periods.

\begin{tabular}{|c|c|c|c|c|c|}
\hline \multirow[t]{2}{*}{ Station } & \multirow[t]{2}{*}{ Period } & \multicolumn{2}{|c|}{ Seeded days } & \multicolumn{2}{|c|}{$\begin{array}{l}\text { Not-seeded } \\
\text { days }\end{array}$} \\
\hline & & $T$ & C & $T$ & $C$ \\
\hline Delhi & $\begin{array}{c}1957-65 \\
\text { excluding } \\
1962\end{array}$ & 1287.9 & 956.6 & 1217.0 & 1280.4 \\
\hline Agra & $1960-65$ & 994.0 & 692.2 & 881.9 & 973.4 \\
\hline Jaipur & $1960-63$ & 437.5 & 329.7 & 623.3 & 557.1 \\
\hline
\end{tabular}

considered in the case of convective clouds, but only in 3 out of those 5 seasons in the case of stratiform type cloud. By applying a Wilcoxon test the effect of seeding was found to be significant in the convective type cloud situations with a significance level of 0.048 . In comparison the stratiform type gave a significance level of 0.421 .

b. Effect of amount of rainfall. All the 867 seedable days considered were classified into two groups of "light" and "heavy" rainfall days depending upon whether the daily amount of precipitation recorded was less than or more than 0.5 inch. The values of the ratio of precipitation in the target and control sectors for the seeded and not-seeded periods thus classified are given in Table 9. A Wilcoxon test applied to the data relating to the combined regions showed Jevels of significance of 0.0078 and 0.0021 , respectively, for heavy and light rain situations. The effect of seeding is thus found to be equally significant in both types of rain situations.

\section{Discussion}

The procedure adopted in the experiment is simple as the operations have been conducted from the ground. The results of the analysis have largely indicated a positive trend. The high levels of significance shown by the

Tabre 7. Significance levels of three statistical tests.

a. $T / C$ ratios for all stations and the continued region.

\begin{tabular}{lccc}
\hline \hline \multirow{2}{*}{ Station } & \multicolumn{3}{c}{ Level of significance (one sided) } \\
& Median ratio & Mann-Whitney & $t$-test \\
\hline Delhi & 0.066 & 0.025 & 0.018 \\
Agra & 0.040 & 0.013 & 0.030 \\
$\begin{array}{l}\text { Jaipur } \\
\begin{array}{l}\text { Delhi, Agra } \\
\text { and Jaipur } \\
\text { combined }\end{array}\end{array}$ & 0.243 & 0.135 & 0.277 \\
& 0.0025 & 0.0004 & 0.004 \\
\hline
\end{tabular}

b. $(\mathrm{Ee} / \mathrm{We}) /(\mathrm{Ew} / \mathrm{Ww})$ for Delhi.

\begin{tabular}{lccc}
\hline Station & \multicolumn{2}{c}{ Level of significance (one sided) } \\
& Median ratio & Mann-Whitney & $t$-test \\
\hline Delhi & 0.005 & 0.001 & 0.019
\end{tabular}


TABLE 8. Rainfall (mm) per station in target $(T)$ and control $(C)$ sectors with respect to cloud type at Delhi.

\begin{tabular}{|c|c|c|c|c|c|c|c|c|c|c|c|c|c|c|}
\hline \multirow[t]{3}{*}{ Year } & \multicolumn{6}{|c|}{ Convective clouds } & \multicolumn{8}{|c|}{ Layer coluds } \\
\hline & \multicolumn{3}{|c|}{ Seeded } & \multicolumn{3}{|c|}{ Not-seeded } & \multirow[b]{2}{*}{ Result } & \multicolumn{2}{|c|}{ Seeded } & & \multicolumn{3}{|c|}{ Not-seeded } & \multirow[b]{2}{*}{ Ressult } \\
\hline & $T$ & C & $T / C$ & $T$ & $C$ & $T / C$ & & $T$ & $C$ & $T / C$ & $T$ & C & $T / C$ & \\
\hline$\overline{1960}$ & 13.7 & 13.0 & 1.05 & 29.7 & 36.8 & 0.81 & Positive & 31.0 & 17.6 & 1.76 & 73.4 & 81.0 & 0.91 & Positive \\
\hline 1961 & 80.5 & 59.7 & 1.35 & 95.5 & 91.9 & 1.04 & Positive & 43.4 & 13.0 & 3.34 & 42.4 & 13.2 & 3.21 & Positive \\
\hline 1963 & 226.3 & 104.4 & 2.16 & 38.9 & 55.6 & 0.70 & Positive & 47.0 & 39.1 & 1.20 & 20.8 & 43.9 & 0.47 & Positive \\
\hline 1964 & 34.0 & 8.4 & 4.05 & 187.7 & 121.9 & 1.54 & Positive & 16.3 & 11.2 & 1.46 & 8.4 & 3.6 & 2.33 & Neagtive \\
\hline 1965 & 61.7 & 68.6 & 0.90 & 7.1 & 41.7 & 0.17 & Positive & 3.0 & 6.6 & 0.45 & 50.0 & 44.7 & 1.12 & Negative \\
\hline
\end{tabular}

parametric ( $t$-test) and non-parametric tests (median ratio and Wilcoxon) point out that the results obtained could be considered as dependable. It is of interest to note in this connection that the limited cloud seeding trials attempted in Pakistan using a similar seeding technique (Fournier D'Albe et al., 1955) have also suggested an increase in rainfall.

The experiment has been carried out in three climatologically similar regions. A cursory examination of Tables $4 a-4 c$; where the result for Jaipur is positive in all the four seasons experimented, would indicate that that region is to be considered as most favorable for warm cloud stimulation. However, this is not really so, since an examination of Tables $4 \mathrm{~d}-4 \mathrm{f}$ points out that the results are more consistently positive at Delhi and next at Agra. So far as Jaipur is concerned the number of positives and negatives obtained are almost equally balanced although the balance considered for the season as a whole is slightly positive in all the four seasons. This feature has been reflected in the results of the statistical analysis (Table 7a) which indicated that the results for Jaipur are the least significant.

A net increase in precipitation of $41.9 \%$ has been indicated in the downwind direction in the present experiment. As all the days which have been associated with frequent or continuous rain during each season have been excluded from the seeding program (warm cloud seeding from ground is not applicable on such occasions), the suggested increase in rainfall as stated above does not signify that the season's total rainfall

TABLE 9. Rainfall $(\mathrm{mm})$ per station in target $(T)$ and control $(C)$ sectors will respect to rainfall amount.

a. Delhi

\begin{tabular}{|c|c|c|c|c|c|c|c|c|c|c|c|c|c|c|c|}
\hline & & \multicolumn{6}{|c|}{ Light rain } & \multicolumn{8}{|c|}{ Heavy rain } \\
\hline & & \multicolumn{3}{|c|}{ Seeded } & \multicolumn{3}{|c|}{ Not-seeded } & \multirow[b]{2}{*}{ Result } & \multicolumn{2}{|r|}{ Seeded } & \multicolumn{4}{|c|}{ Not-seeded } & \multirow[b]{2}{*}{ Result } \\
\hline & & $T$ & $C$ & $T / C$ & $T$ & $C$ & $T / C$ & & $T$ & $C$ & $T / C$ & $T$ & $C$ & $T / C$ & \\
\hline 1957 & & 44.0 & 16.6 & 2.65 & 44.3 & 51.1 & 0.87 & Positive & 84.7 & 106.0 & 0.08 & 41.5 & 93.5 & 0.44 & Positive \\
\hline 1958 & & 82.0 & 122.5 & 0.67 & 23.8 & 64.3 & 0.37 & Positive & 61.7 & 63.2 & 0.98 & 100.1 & 141.7 & 0.71 & Positive \\
\hline 1959 & & 82.3 & 40.2 & 2.05 & 36.8 & 40.6 & 0.91 & Positive & 78.0 & 95.0 & 0.82 & 136.2 & 98.3 & 1.39 & Negative \\
\hline 1960 & & 25.3 & 22.9 & 1.10 & 38.5 & 60.1 & 0.64 & Positive & 34.9 & 29.4 & 1.19 & 120.1 & 86.8 & 1.38 & Negative \\
\hline 1961 & & 66.0 & 25.0 & 2.64 & 109.2 & 64.5 & 1.69 & Positive & 99.6 & 78.0 & 1.28 & 42.9 & 115.8 & 0.37 & Positive \\
\hline 1963 & & 53.4 & 36.5 & 1.46 & 45.9 & 72.0 & 0.64 & Positive & 219.6 & 107.1 & 2.05 & 16.8 & 27.4 & 0.61 & Positive \\
\hline 1964 & ' & 43.9 & 33.0 & 1.33 & 44.8 & 56.1 & 0.80 & Positive & 261.9 & 137.4 & 1.91 & 358.9 & 223.0 & 1.61 & Positive \\
\hline 1965 & & 14.3 & 27.8 & 0.51 & 27.7 & 52.4 & 0.53 & Negative & 36.3 & 16.0 & 2.27 & 29.5 & 33.8 & 0.87 & Positive \\
\hline & & & & & & & & Agra & & & & & & & \\
\hline
\end{tabular}

\begin{tabular}{|c|c|c|c|c|c|c|c|c|c|c|c|c|c|c|}
\hline \multirow[t]{3}{*}{ Year } & \multicolumn{6}{|c|}{ Light rain } & \multicolumn{8}{|c|}{ Heavy rain } \\
\hline & \multicolumn{3}{|c|}{ Seeded } & \multicolumn{3}{|c|}{ Not-seeded } & \multicolumn{4}{|c|}{ Seeded } & \multicolumn{3}{|c|}{ Not-seeded } & \multirow[b]{2}{*}{ Result } \\
\hline & $T$ & $C$ & $T / C$ & $T$ & $C$ & $T / C$ & Result & $T$ & $C$ & $T / C$ & $T$ & $C$ & $T / C$ & \\
\hline 1960 & 27.3 & 8.7 & 3.14 & 14.0 & 34.7 & 0.40 & Positive & 196.4 & 146.4 & 1.34 & 84.1 & 76.5 & 1.10 & Positive \\
\hline 1961 & 32.3 & 38.6 & 0.84 & 59.3 & 37.0 & 1.60 & Negative & 176.7 & 122.0 & 1.45 & 46.0 & 53.2 & 0.87 & Positive \\
\hline 1962 & 48.7 & 45.9 & 1.06 & 72.1 & 53.3 & 1.24 & Negative & 58.2 & 89.1 & 0.65 & 113.8 & 123.0 & 0.93 & Negative \\
\hline 1963 & 49.4 & 20.5 & 2.41 & 46.2 & 46.3 & 1.00 & Positive & 62.5 & 55.8 & 1.12 & 164.1 & 231.6 & 0.71 & Positive \\
\hline 1964 & 102.6 & 52.5 & 1.96 & 61.3 & 68.4 & 0.90 & Positive & 43.2 & 18.5 & 2.34 & 66.3 & 102.0 & 0.65 & Positive \\
\hline 1965 & 52.9 & 13.9 & 3.81 & 10.0 & 20.5 & 0.49 & Positive & 143.8 & 80.4 & 1.79 & 135.0 & 123.4 & 1.09 & Positive \\
\hline & & & & & & & Jaipur & & & & & & & \\
\hline
\end{tabular}

\begin{tabular}{|c|c|c|c|c|c|c|c|c|c|c|c|c|c|c|}
\hline & & & Lig. & & & & & & & Hea & rain & & & \\
\hline & & eeded & & & t-seed & & & & eeded & & & -seede & & \\
\hline & $T$ & $C$ & $T / C$ & $T$ & $C$ & $T / C$ & Result & $T$ & $C$ & $T / C$ & $T$ & $C$ & $T / C$ & Result \\
\hline 1960 & 46.0 & 32.5 & 1.42 & 94.2 & 58.6 & 1.61 & Negative & 85.8 & 42.2 & 2.04 & 39.9 & 20.6 & 1.94 & Positive \\
\hline 1961 & 57.2 & 45.8 & 1.25 & 86.4 & 120.2 & 0.72 & Positive & 81.5 & 72.6 & 1.12 & 99.6 & 58.9 & 1.69 & Negative \\
\hline 1962 & 23.5 & 31.8 & 0.74 & 61.4 & 83.8 & 0.73 & Positive & 66.5 & 54.1 & 1.23 & 119.5 & 97.8 & 1.22 & Positive \\
\hline 1963 & 39.9 & 26.6 & 1.50 & 90.7 & 72.8 & 1.25 & Positive & 37.1 & 24.1 & 1.54 & 31.6 & 43.5 & 0.73 & Positive \\
\hline
\end{tabular}


could be increased to that extent as a result of ground seeding. In fact, it will be much less. If the total rain received on the days excluded from seeding accounts for half of the season's total, which is so on the average, this means that only about a $21 \%$ increase in the season's total is what is to be expected. Further, considering that the seeding operation conducted has been limited to only $3-5 \mathrm{hr}$ in the course of the day while the 24-hr total rainfall as recorded by the raingages in the test areas has been taken into account for analysis, the figure of $21 \%$ has to be treated only as an upper limit. Also, in accepting this, it is to be remembered that the results obtained for the three regions Delhi, Agra and Jaipur have been combined and that the validity of combining the results of different regions might be questionable.

\section{Conclusion}

Since the generators were operated from the ground, there is the uncertainty that the particles released may not have reached cloud heights and that the suggested overall positive trend of the results in the experiment is fortuitous. While seeding from aircraft eliminates one of the major uncertainties, it is relatively uneconomical in practice, especially as far as warm cloud seeding is concerned. It is necessary, therefore, to obtain a clear picture of the trajectory of the particles released from the ground generators. A study in this direction is now being contemplated, especially in view of the fact that the results for the 18 experiment seasons has been significantly positive. Proof that the particles enter the clouds would render the results more realistic.

Acknowledgments. The authors wish to express their grateful thanks to Mr. A. K. Roy for the helpful discussions they had in the course of preparing this paper.

\section{REFERENCES}

Fisher, R. A., and F. Yates, 1953: Statistical Tables for Biological, Agricultural and Medical Research. London, Oliver and Boyd, 114-119.

Fournier D'Albe, E. M., A. M. A. Lateef, S. I. Rasool and I. Saidi, 1955: The cloud seeding trials in the central Punjab, July-September 1954. Quarl. J. Roy. Meteor. Soc., 81, 574-581.

Kendall, M. G., 1943: The Advanced Theory of Statistics. Vol. 1, 1st ed., London, Charles Griffin and Ca., Ltd., 303-304.

Mann, H. B., and D. R. Whitney, 1947: On a test of whether one of two random variables is stochastically larger than the other. Ann. Math. Stat., 18, 50-60.

Moran, P. A. P., 1959: The power of a crossover test for the artificial stimulation of rain. Australian J. Stat., 1, 47-52.

Roy, A. K., Bh. V. Ramana Murty, R. C. Srivastava and L. T. Khemani, 1961: Cloud seeding trials at Delhi during monsoon, months, July to September (1957-1959). Indian J. Meleor. Geophys., 12, 401-412.

,,-- K. R. Biswas and L. T. Khemani, 1964: Cloud seeding experiments around Delhi using aircraft. Indian. J. Sci. Ind. Res., 23, 326-333.

Sutton, O. G., 1953: Micrometeorology. New York, McGraw-Hill Book Co., Inc., 273-277.

Siliceo, E. Perez., A. Ahumada A. and P. A. Mosiño, 1963: Twelve years of cloud seeding in the Necaxa Watershed, Mexico. J. Appl. Meteor., 2, 311-323. 